\title{
Effects of Prolonged Darkness on Light Responsiveness and Spectral Sensitivity of Cone Horizontal Cells in Carp Retina in vivo
}

\author{
Xiong-Li Yang, Tian-Xin Fan, and Wen Shen \\ Shanghai Institute of Physiology and Shanghai Joint Laboratory of Life Science, Chinese Academy of Sciences, Shanghai \\ 200031, China
}

Light responses of cone- and rod-driven horizontal cells were recorded intracellularly from opened eyes of intact, immobilized carp and the effects of prolonged darkness on these cells were examined. When the retina was left in the dark, responses of cone horizontal cells to a moderate test flash presented once every $\mathbf{1 0}$ min gradually and steadily decreased in size (dark suppression effect). Following a repetitive presentation of the test flash, the light responsiveness of the cells was enhanced. In contrast, the rod horizontal cells did not show the dark suppression effect and the light responsiveness of these cells increased in the dark.

Effects of prolonged darkness on the spectral sensitivity of L-type and R/G-type cone horizontal cells were also studied. The spectral sensitivity of L-type cells, determined just after background illumination was extinguished, agreed reasonably well with that of red-sensitive (R-) cones, but it matched better that of green-sensitive (G-) cones when determined in prolonged darkness. We further show that depolarizing responses of R/G-type cone horizontal cells to long-wavelength flashes, driven by R-cones, were abolished after prolonged darkness. Taken together, these results suggest that input from R-cones converging onto the cone horizontal cells is more significantly suppressed after prolonged dark adaptation than input from G-cones. Due to the suppression of the R-cone input, enhancement of responses of the L-type cone horizontal cells to long-wavelength stimulation in the presence of a green background light was no longer seen after prolonged darkness. Following intraocular injections of 6-hydroxydopamine (6-OHDA), cone horizontal cells were still partially suppressed in the dark, but the suppression was much less significant than that observed in untreated retinas, suggesting the involvement of dopamine in the dark suppression effect. Partial dark suppression of cone horizontal cells observed in 6-OHDA-treated retinas also suggests that a substance(s) other than dopamine may contribute to the dark suppression effect.

[Key words: horizontal cells, prolonged darkness, cones, retina, light responsiveness]

\footnotetext{
Received Nov. 30, 1993; revised June 29, 1993; accepted July 6, 1993.

We are indebted to Prof. J.E. Dowling for his critical comments. This research was supported by grants from the National Science Foundation of China (3870203), the National Institute of Health (EY08338), and International Human Frontier Science Program Organization. J.D. Li and W. Yan took part in some of the earlier experiments.

Correspondence should be addressed to Xiong-Li Yang, Shanghai Institute of Physiology, Chinese Academy of Sciences, Shanghai 200031, China.

Copyright (C) 1994 Society for Neuroscience 0270-6474/94/140326-09\$05.00/0
}

In the teleost fish retina, the horizontal cells form several distinct layers along the distal margin of the inner nuclear layer (Parthe, 1982). Short-axon horizontal cells, which are located more distally in the retina, appear to connect exclusively with cones (cone horizontal cells), whereas axonless horizontal cells. the most proximally located of all horizontal cells, connect exclusively with rods (rod horizontal cells) (Stell et al.. 1982). In recent years, several studies (Mangel and Dowling, 1987; Yang et al., 1988a) have shown in isolated fish retinas that the light responsiveness of L-type cone horizontal cells is suppressed in prolonged darkness (dark suppression effect). That is, the responses of these cells to full-field stimuli, recorded from carp or white perch retinas isolated from animals dark-adapted for more than $2 \mathrm{hr}$, were much smaller than the responses recorded from retinas isolated from animals dark-adapted for just 30-40 $\mathrm{min}$. Since L-type cone horizontal cells receive inputs from both red-sensitive ( $R$-) cones and green-sensitive (G-) cones (Yang et al., 1982, 1983), it is of interest to see whether the cone inputs to the horizontal cells are equally suppressed in prolonged darkness. In this study, we made intracellular recordings from opened eyes of intact, immobilized fish and examined the effects of longterm dark adaptation on both cone and rod horizontal cells. The in vivo preparation presumably permits the study of light and dark adaptation under conditions similar to those that occur in the intact animal. We confirmed that cone horizontal cells were suppressed in prolonged darkness in the in vivo preparation, whereas rod horizontal cells maintained high light responsiveness. Furthermore, we found that spectral responses of both L-type and C-type cone horizontal cells were significantly altered by prolonged darkness. It was suggested previously that the interplexiform cells may release dopamine in prolonged darkness and that dopamine may cause the dark suppression effect (Yang et al., 1988b). We examined this also in our in vivo preparation and found that the dark suppression effect was much less significant after the destruction of the dopaminergic interplexiform cells by 6-hydroxydopamine (6-OHDA), but it persisted. This suggests that a substance(s) other than dopamine also may be involved in the dark suppression effect.

\section{Materials and Methods}

Preparations. Preparations were made as described previously (Yang et al., 1982, 1983, 1990; Yang, 1987). In short, carp (Carassius carassius; body length, $15-20 \mathrm{~cm}$ ) were anesthetized by immersion in a $0.03 \%$ solution of tricaine methanesulfonate, immobilized by intramuscular injection of gallamine triethiodide $(25 \mathrm{mg} / \mathrm{kg})$, and maintained by aerated water that continuously irrigated the gills. The extraocular muscles of the left eye, which was exposed above the water level, were sectioned, and the eye was held securely with a spoon-shaped holder placed behind the eyeball. Cornea and lens were removed with care to avoid bleeding 
due to injury to the iris. The animal was positioned on a double $X-Y$ stage, by which both preparation and microelectrode could be moved independently or together in relation to the light stimulus spot. The surgical procedures were performed under room light illumination (125 lux on the retinal surface).

Photostimulation. A photostimulator equipped with two almost identical optical paths was used and has been described elsewhere (Yang, 1987). The spot diameter of each beam could be varied from $0.25 \mathrm{~mm}$ to $2.5 \mathrm{~mm}$, but in the present experiments, both beams were set to present a $2.5-\mathrm{mm}$-diameter diffuse spot centered around the electrode tip. Interference filters $(10 \mathrm{~nm}$ at half-height) were used to alter the spectral properties of each beam to suit the needs of the experiment. Light intensities of all wavelengths were measured with a calibrated photodetector (UDT-222, United Detector Technology, Santa Monica, CA). The intensity of the unattenuated $680 \mathrm{~nm} \operatorname{light}(\log I=0)$ was $2.18 \times 10^{15}$ quanta $\mathrm{cm}{ }^{2} \mathrm{sec}{ }^{1}$ and all light intensities referred to in the text are in $\log$ units relative to this value. The intensity of the unattenuated white light was $1.29 \times 10^{\prime} \mu \mathrm{W} \mathrm{cm}^{2} \mathrm{sec}^{-1}$. The duration of the light stimuli was controlled by a magnetic shutter (Hirogo, M5-101) and set at $500 \mathrm{msec}$ for the test flashes.

Electrical recordings and experimental procedures. For intracellular recordings, micropipettes were filled with $3 \mathrm{M}$ potassium acetate, and they had resistances of 50-100 Ms when measured in the vitreous humor. A hydraulic micromanipulator was used to advance the electrode into the retina. Cell penetration was facilitated by briefly $(5 \mathrm{msec})$ oscillating the preamplifier circuit (Nihon Koden, MEZ 8201). Electrical responses of retinal cells were displayed on a storage oscilloscope and stored on a data recorder (Sony, DC-625 Hz $\pm 3 \mathrm{dR}$ ). Raw data were sequentially sampled at $5 \mathrm{msec}$ intervals and processed further by the APRES I System (Computer Laboratory, Shanghai Institute of Physiology, Chinese Academy of Sciences).

After the surgical procedures were performed, the animal was darkadapted for $10 \mathrm{~min}$. To study the dark suppression effect, the retina was usually preexposed to a bright white light $(\log I=0)$ for $1 \mathrm{~min}$ and then left in the dark. Interflash time was set at $15 \mathrm{sec}$. Data collection was made at intervals of $3 \mathrm{~min}$ in the first $10 \mathrm{~min}$ in darkness and subsequently at intervals of $10 \mathrm{~min}$. Flashes of higher intensities were not delivered whenever possible to avoid disturbing the dark-adapted state of the retina. Any specific additions or changes to these procedures are noted in the text.

Identification of horizontal cells. The different types of horizontal cells were identified by previously established criteria (Werblin and Dowling, 1969; Kaneko, 1970; Kaneko and Yamada, 1972; Yang et al., 1982, 1988a; Yang, 1987). All horizontal cells recorded were characterized by their sustained, graded responses with large, uniform receptive fields. L-type cone horizontal cells hyperpolarized in response to all spectral stimuli with a peak sensitivity of about $600 \mathrm{~nm}$. These cells were located most distally in the retina. Responses of C-type horizontal cells changed in polarity depending on the stimulus wavelength. In this study only $\mathrm{R} / \mathrm{G}$-type horizontal cells, which hyperpolarized to short and intermediate regions of the spectrum but depolarized to deep red $(>680 \mathrm{~nm})$ stimuli, were studied. These cells reside more proximally in the retina than do L-type cone horizontal cells. Rod horizontal cells were the most proximally located of all horizontal cells and they were at least 2 log units more sensitive to white light than were L-type cone horizontal cells.

Intraocular injection of 6-OHDA. Injections of $10 \mu$ of 6-hydroxydopamine (6-OHDA) (Sigma; $9 \mathrm{mg} / \mathrm{ml}$ in $0.9 \% \mathrm{NaCl}$, with $2 \mathrm{mg} / \mathrm{ml}$ ascorbate added as an antioxidant) were made into both eyes of a carp on two consecutive days, 1 week before the recording experiment, a treatment that has been used for depleting dopamine from the retina (Yang et al., 1988b). This dosage was chosen because immunohistochemical examination showed that following the injections, terminals and cell bodies of the dopaminergic interplexiform cells were destroyed, whereas electroretinographic responses remained intact and unaffected, being comparable in size to those recorded from untreated retinas under the same adapting conditions (X.-L. Yang, T.-X. Fan, and W. Shen, unpublished observations).

\section{Results}

Dark adaptation of L-type cone horizontal cells

We first studied the course of dark adaptation in L-type cone horizontal cells in the in vivo preparation. After a preparation was set up under room illumination, it was first dark-adapted for $10 \mathrm{~min}$. When an L-type cone horizontal cell was impaled, a $680 \mathrm{~nm}$ flash of moderate intensity $(500 \mathrm{msec}, \log I=-0.19)$ was repetitively presented at $1 \mathrm{~Hz}$ until the response of the cell attained a maximum value. The retina was then left in the dark and both membrane potential and light responsiveness of the cell were recorded over the course of $60 \mathrm{~min}$. Figure $1 \mathrm{a}$ shows responses of a representative cone horizontal cell to the flash $(680 \mathrm{~nm}, \log I=-0.19)$, delivered at intervals of $10 \mathrm{~min}$ in the dark. The first response $(0 \mathrm{~min})$ was $32 \mathrm{mV}$, but it was gradually and steadily reduced in size with time and was only $6.5 \mathrm{mV}$ in amplitude after $60 \mathrm{~min}$ in darkness. The retina was then reexposed to the repetitively presented flashes. The cell slowly hyperpolarized by about $5 \mathrm{mV}$ in the first $1.5 \mathrm{~min}$; thereafter the membrane potential remained constant. In the meantime, response amplitudes increased and attained a value of $30 \mathrm{mV}$ after about $4 \mathrm{~min}$. When the repetitive flashes ceased, the membranc potential returned to its initial level (that at $0 \mathrm{~min}$ ). Figure $1 b$ shows the average change in membrane potential for a number of L-type cone horizontal cells $(n=12)$ as a function of time in the dark. During the course of dark adaptation the membrane potential fuctuated irregularly around a level $(-30 \mathrm{mV})$ recorded just after the offset of the repetitive flashes. The average change of response amplitudes during the same period of time is shown in Figure $1 c$. The response amplitude to the test light recorded at $0 \mathrm{~min}$ was on average $31.6 \pm 4.6 \mathrm{mV}$ (mean $\pm \mathrm{SD}$, $n=12$ ), whereas it was $6.5 \pm 3.5 \mathrm{mV}$ at $60 \mathrm{~min}$. Four cells were held for more than $150 \mathrm{~min}$ and the responses recorded at $150 \mathrm{~min}$ in the dark were $4.44 \pm 0.99 \mathrm{mV}$.

\section{Dark adaptation of rod horizontal cells}

Whereas the responses of the cone horizontal cells were suppressed in the dark, rod horizontal cells did not lose their light responsiveness after prolonged darkness. Figure 2 shows changes in responsiveness and membrane potential of a rod horizontal cell in the dark. The response of the cell to a test light $(680 \mathrm{~nm}$, $\log I=-0.41$ ), shown at far left in the upper row, was recorded after $120 \mathrm{~min}$ in the dark and served as control. The retina was then exposed to a white bright light $(\log I=0)$ for $1 \mathrm{~min}$, which hyperpolarized the cell by $54 \mathrm{mV}$. With time in the dark, the cell slowly depolarized and returned to the dark level over a period of $90 \mathrm{~min}$ (Fig. $2 \mathrm{~b}$ ). Responses of the cell to the test flash recorded at different times in the dark are shown in the upper row (Fig. 2a). The cell initially showed no response until $9 \mathrm{~min}$, when a response with an initial transient emerged. The response increased in size with further time in the dark and a complete recovery of the light responsiveness of the cell required $90 \mathrm{~min}$.

\section{Signals from $R$ - and $G$-cones were differentially affected by prolonged darkness}

Although the spectral sensitivity of L-type cone horizontal cells peaks around $600 \mathrm{~nm}$ under normal conditions, these cells have been shown to receive signals from both $R$ - and G-cones (Yang et al., 1982, 1983). To test whether signals from $R$ - and $G$-cones to the cells are equally or differentially affected by prolonged darkness, we examined the responses of the L-type cone horizontal cells during dark adaptation, using $500 \mathrm{~nm}$ and $680 \mathrm{~nm}$ test flashes. These wavelengths were selected because $500 \mathrm{~nm}$ and $680 \mathrm{~nm}$ flashes predominantly activate G-cones and R-cones, respectively (Yang et al., 1982). Figure 3 illustrates the results of this type of experiment on an L-type cone horizontal cell. The retina was preexposed to a bright white light $(\log I=0)$ for $1 \mathrm{~min}$ and then left in the dark. Changes in responses elicited 
a

Time in darkness $(\mathrm{min})$

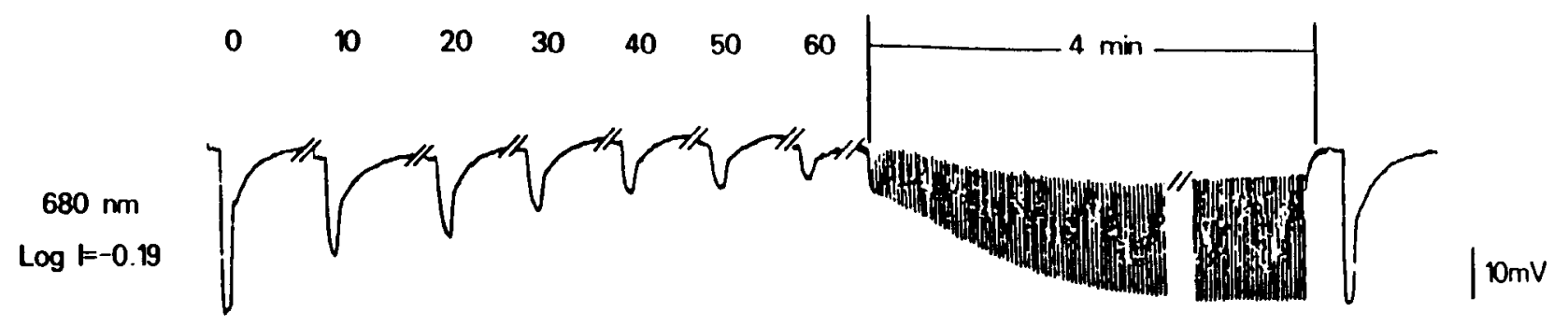

b

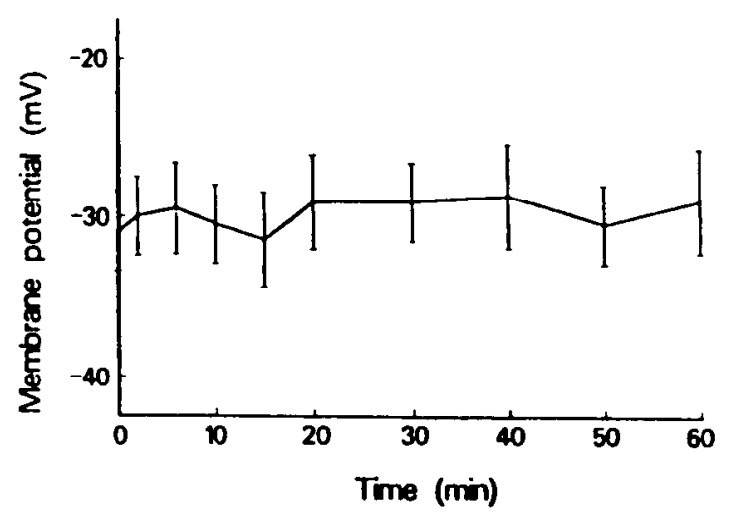

c

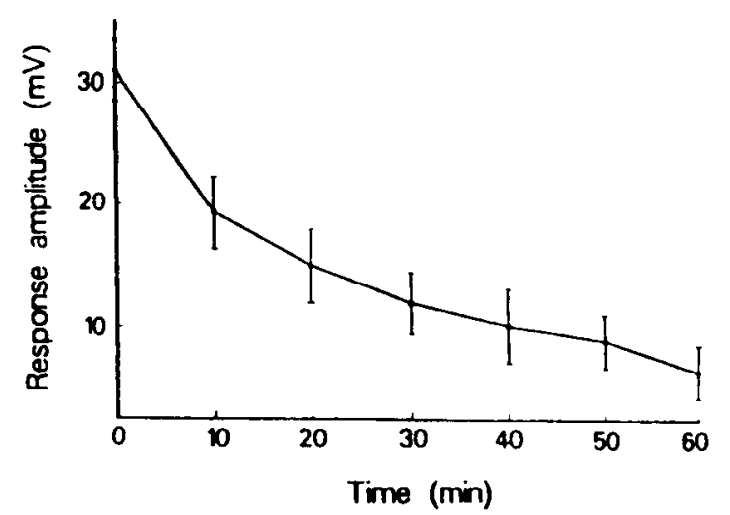

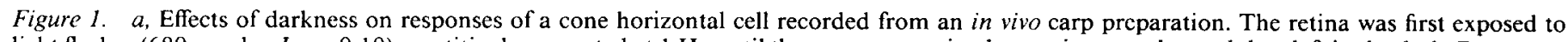

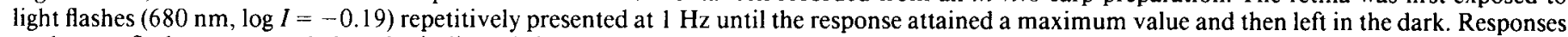

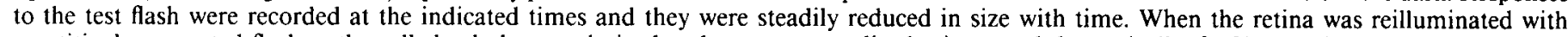

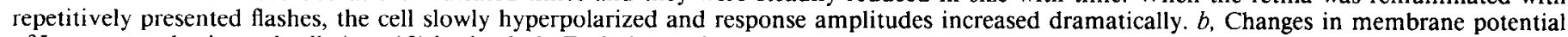

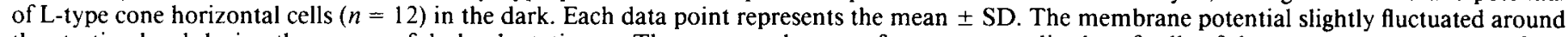

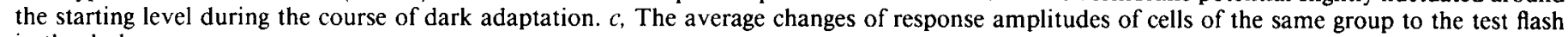
in the dark.

by $500 \mathrm{~nm}$ and $680 \mathrm{~nm}$ flashes were monitored during the course of dark adaptation. For both wavelengths, flashes of two intensities were used, with the brighter pair $(500 \mathrm{~nm}, \log I=-1.14$; $680 \mathrm{~nm}, \log I=-0.19)$ chosen so as to elicit responses of comparable amplitude. The response to the brighter $500 \mathrm{~nm}$ flash recorded at $3 \mathrm{~min}$ in the dark was characterized by a conspicuous on-transient, which was absent in the response to the brighter $680 \mathrm{~nm}$ flash. The relative intensities of the dimmer pair were chosen so that the response of the cell to the $680 \mathrm{~nm}$ flash $(\log I=-3.00)$ was bigger than that to the $500 \mathrm{~nm}$ flash $(\log I=-3.20)$. Although both the responses to the brighter $500 \mathrm{~nm}$ and $680 \mathrm{~nm}$ flashes were significantly reduced in amplitude following $65 \mathrm{~min}$ of darkness, the response to the 500 $\mathrm{nm}$ flash became bigger than that to the $680 \mathrm{~nm}$ flash. It is particularly worth noting that the changes in responses to the dimmer $500 \mathrm{~nm}$ and $680 \mathrm{~nm}$ flashes were just the opposite. That is, the response to the $500 \mathrm{~nm}$ flash increased from $2 \mathrm{mV}$ to $4 \mathrm{mV}$, whereas the one to the $680 \mathrm{~nm}$ flash decreased from $5 \mathrm{mV}$ to $1.5 \mathrm{mV}$ !

We determined light intensity versus response amplitude ( $V-$ $\log I$ ) relationships for $680 \mathrm{~nm}$ and $500 \mathrm{~nm}$ at different times in the dark to analyze further differential effects of prolonged darkness on signals from $\mathrm{R}$ - and $\mathrm{G}$-cones to L-type cone horizontal cells. Figure $4 a$ shows $V-\log I$ curves of the cell shown in Figure 3, which were determined at different times in the dark using $680 \mathrm{~nm}$ test flashes. Following a 1 min exposure to a bright white light $(\log I=0)$, the light responsiveness changed so fast in the first minute that only two solitary data points at $10 \mathrm{sec}$ and $1 \mathrm{~min}$ for $680 \mathrm{~nm}$ could be obtained. The light responsiveness of the cell attained a maximum valuc at $2.5 \mathrm{~min}$ and the $V-\log I$ curve determined at that time was quite steep. Note that the response amplitudes of the cell recorded at 2.5 min were larger than those recorded at $10 \mathrm{sec}$ and $1 \mathrm{~min}$, an indication of some photoreceptor adaptation. $V-\log I$ relationships were determined at intervals of $3 \mathrm{~min}$ in the first $10 \mathrm{~min}$, but at intervals of $10 \mathrm{~min}$ thereafter. The cell maintained its higher light responsiveness for about $10 \mathrm{~min}$ and then light responsiveness of the cell started to decrease. $V$-log $I$ curves determined thereafter became less steep with time in the dark and the response amplitude increased only by $3.5 \mathrm{mV}$ over a range of $3 \mathrm{log}$ units at $150 \mathrm{~min}$ in the dark. It should be noted that all responses to flashes of various intensities uniformly decreased in amplitude. On the other hand, changes in $V-\log I$ curves elicited with $500 \mathrm{~nm}$ flashes during dark adaptation were somewhat different (Fig. $4 b$ ). As compared with those determined at $4 \mathrm{~min}$, at which time the $V-\log I$ curve was steepest of all the curves, the response of the cell to a brighter flash (log $I=-1.14$ ) determined at $17 \mathrm{~min}$ was slightly reduced, from 35 $\mathrm{mV}$ to $32 \mathrm{mV}$, but those to dimmer flashes $(\log I=-1.85$, -2.72 , and -3.20 ) were slightly increased. This tendency per- 


\section{Rod HC}

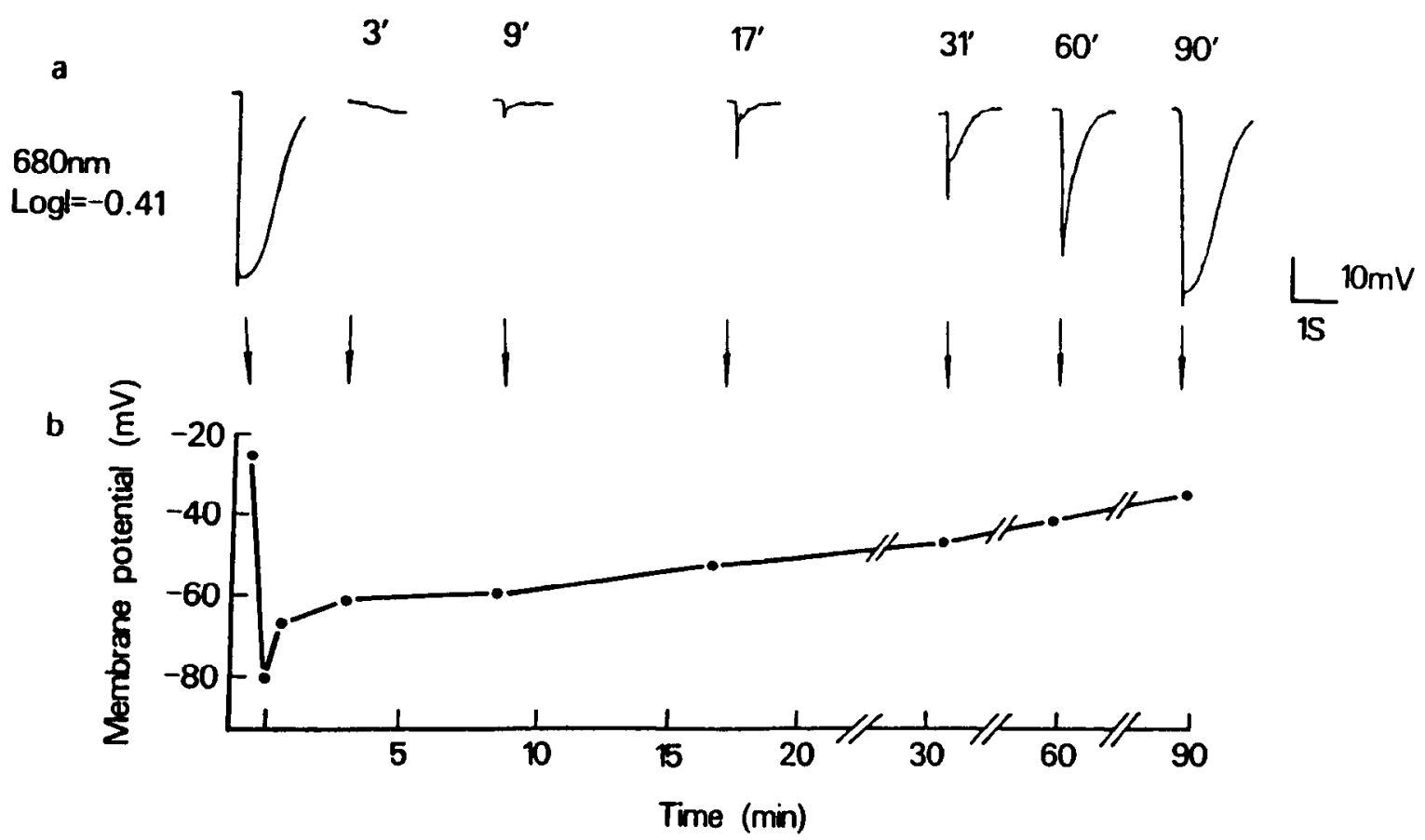

Figure 2. Dark adaptation of a rod horizontal cell. The retina was dark-adapted for more than 2 hr before exposure to a 1 min white light (log $I$ $=0$ ), which hyperpolarized the cell by $54 \mathrm{mV}$. Membrane potential of the cell was monitored in the dark and it returned to the dark level over a period of $90 \mathrm{~min}$ after the offset of the background light $(b)$. Responses to a test light $(680 \mathrm{~nm}, \log I=-0.41)$ recorded at different times in the dark are shown in $a$. No response could be elicited until $9 \mathrm{~min}$ in the dark and complete recovery of the light responsiveness of the cell required about $90 \mathrm{~min}$.

sisted with time in the dark, such that the response elicited by a flash of $\log I=-3.20$ increased in size from $1.6 \mathrm{mV}$ at $4 \mathrm{~min}$ to $4 \mathrm{mV}$ at $63 \mathrm{~min}$, whereas that to the brighter flash $(\log I=$ -1.14) dropped from $35 \mathrm{mV}$ to $8.5 \mathrm{mV}$ over this period of darkness. Similar results were obtained in five other cells.

The results described so far suggest that the spectral sensitivity of the L-type cone horizontal cells changes with time in the dark. This is indeed the case and one representative experiment is shown in Figure 5, in which our data are superimposed on spectral sensitivity curves of $\mathrm{R}$-cones and $\mathrm{G}$-cones drawn from the data of Hárosi and MacNichol (1974) and modified by Spekreijse et al. (1981). In this case the sensitivity of the L-type cone horizontal cell, defined as the reciprocal of the light intensity giving rise to a $2 \mathrm{mV}$ criterion response amplitude, was determined only at 500,600 , and $680 \mathrm{~nm}$ to avoid disturbing the dark-adapted state of the retina. Sensitivities determined at 4 $\mathrm{min}$ in the dark showed fairly good agreement with that of $\mathrm{R}$-cones, indicating that the $\mathrm{R}$-cones provided the dominant
$500 \mathrm{~nm}$

In

darkness

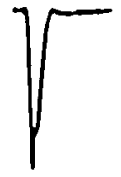

Logl
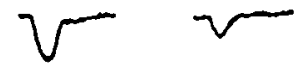

$65 \mathrm{~min}$

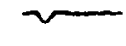

7

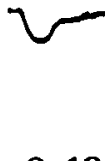

$680 \mathrm{~nm}$

$-0.19-3.00$

Figure 3. The changes in responses to $500 \mathrm{~nm}$ and $680 \mathrm{~nm}$ flashes of an L-type cone horizontal cell during prolonged darkness. The retina was preexposed to a bright white light $(\log I=0)$ for $1 \mathrm{~min}$. Flashes of two intensities were presented at each wavelength. Note that the response to the $500 \mathrm{~nm}$ flash of lower intensity $(\log I=3.20)$ incrcased in size with increasing time in the dark, whereas that to the flash of higher intensity $(-1.14)$ decreased in size. Responses to $680 \mathrm{~nm}$ flashes of either low $(-3.00)$ or high intensities $(-0.19)$ were reduced in size after $65 \mathrm{~min}$ in darkness. 
Figure 4. Changes of response amplitude versus light intensity $(V-\log I)$ relationships of the same cell, as shown in Figure 3, during prolonged dark adaptation. Flashes of $680 \mathrm{~nm}$ and 500 $\mathrm{nm}$ were used as test lights. The retina was preexposed to a white light $(\log I$ $=0$ ) for $1 \mathrm{~min}$. For $680 \mathrm{~nm}$ flashes, the $V-\log I$ curve recorded at $2.5 \mathrm{~min}$ in the dark was the steepest and thereafter the curves became less steep $(a)$. For $500 \mathrm{~nm}$ flashes, responsc amplitudes to dimmer flashes increased in size with time in the dark, whereas those to brighter flashes decreased in size $(b)$. The time in the dark at which curves were determined is indicated beside each curve.

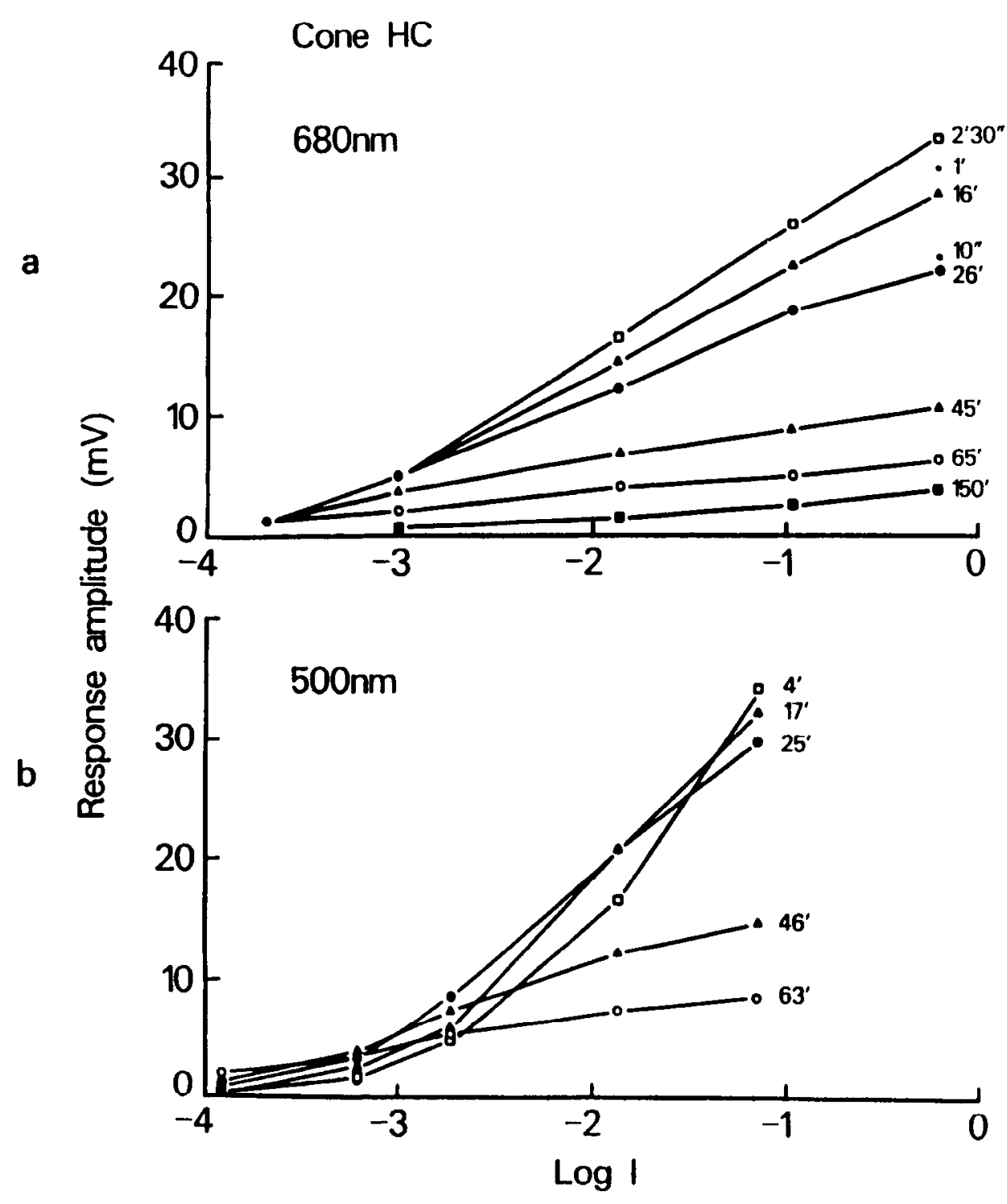

input to the cell. With increasing time in the dark, however, the relative sensitivities at $600 \mathrm{~nm}$ and $680 \mathrm{~nm}$, as compared with that at $500 \mathrm{~nm}$, steadily decreased and the sensitivities for the three wavelengths determined at $65 \mathrm{~min}$ matched better the spectral sensitivity of the G-cones. Similar results were obtained in 10 other cells, suggesting that input signals from R-cones to L-type cone horizontal cells were more strongly suppressed in prolonged darkness than that from $\mathrm{G}$-cones (see Discussion).

\section{Dark adaptation of $R / G$-type biphasic horizontal cells}

In the $\mathrm{R} / \mathrm{G}$-type biphasic horizontal cells it has been demonstrated that input from $\mathrm{G}$-cones hyperpolarizes the cells whereas $\mathrm{R}$-cone input depolarizes them (Yang et al., 1987). We previously reported that the light responsiveness of these cells was also suppressed following prolonged darkness (Yang et al., 1988a). Here we further examined changes in response waveforms of $\mathrm{R} / \mathrm{G}$-type biphasic horizontal cells using $500 \mathrm{~nm}$ and $680 \mathrm{~nm}$ test flashes to see if input from the R-and G-cones to these cells is differentially suppressed in prolonged darkness. The results are shown in Figure 6. The retina was first exposed to a $1 \mathrm{~min}$ white light $(\log I=0)$, and responses to $500 \mathrm{~nm}$ and $680 \mathrm{~nm}$ flashes were recorded at $2 \mathrm{~min}$ (after illumination) and $150 \mathrm{~min}$ in the dark (prolonged darkness). The response to the $500 \mathrm{~nm}$ flash $(\log I=-1.14)$ was a hyperpolarizing one, which became much slower in both its rising and returning phases by $150 \mathrm{~min}$ and decreased in amplitude from $35 \mathrm{mV}$ to $12.5 \mathrm{mV}$ over this period. Responses to $680 \mathrm{~nm}$ flashes recorded just after the offset of the background light had various waveforms, depending on the stimulus intensity: the response to a bright $680 \mathrm{~nm}$ flash $(\log I=-0.19)$ consisted of an initial hyperpolarizing component, presumably driven by input from G-cones, and a depolarizing one driven by input from $\mathrm{R}$-cones. As the flash became dimmer $(\log I=-0.97)$ the response was entirely depolarizing, with an inflection on its rising phase reflecting the hyperpolarizing component. The depolarizing component diminished in size with a further decrease of the flash intensity $(\log I=-1.86$, $-3.01,-3.69)$. When the preparation was left in the dark for $150 \mathrm{~min}$, the responses of the cell to the same series of flashes were greatly changed: they were invariably hyperpolarizing, whether the test flash was bright or dim, and the depolarizing component was almost completely abolished. 


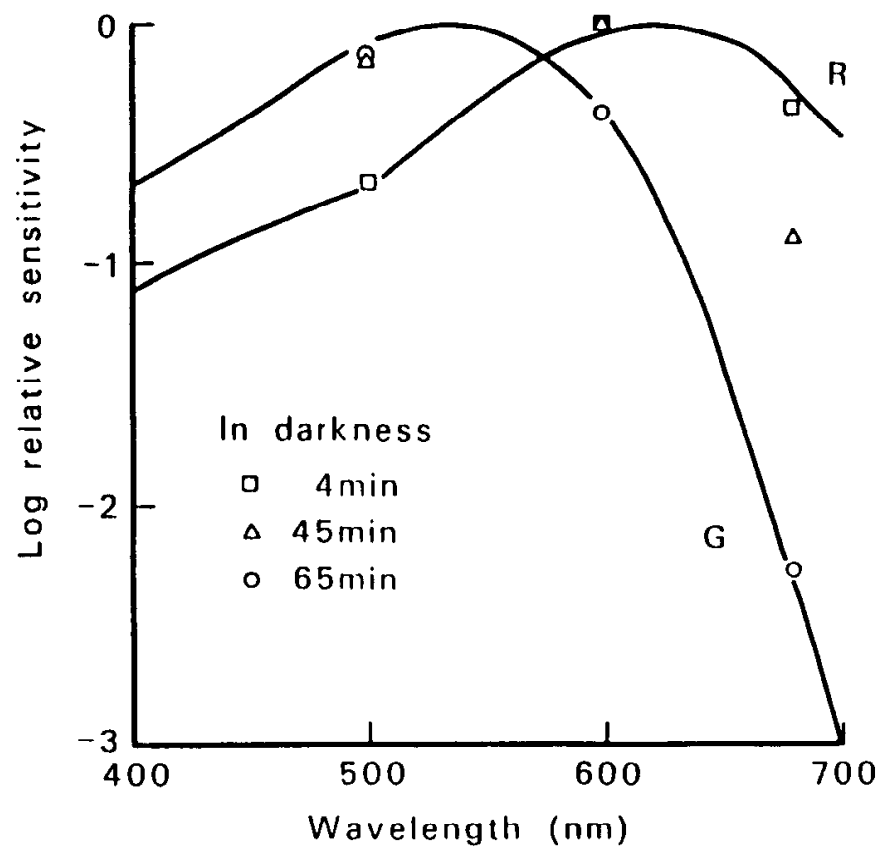

Figure 5. Spectral sensitivities of an L-type cone horizontal cell determined at 4,45 , and $65 \mathrm{~min}$ in the dark after exposing the retina to a $1 \mathrm{~min}$ white light $(\log I=0)$. Relative sensitivities at 500,600 , and $680 \mathrm{~nm}$ determined at 4 min agreed reasonably well with those of the red-sensitive cones. However, sensitivities for these wavelengths determined at 65 min coincided with those of the green-sensitive cones. Data determined at $45 \mathrm{~min}$ were intermediate between them. Spectral sensitivity curves of red- and green-sensitive cones of carp are based on the data of Hárosi and MacNichol (1974), modified by Spekreijse et al. (1981), and are indicated by $R$ and $G$, respectively.

\section{Effects of prolonged darkness on the interactions between inputs from $R$ - and $G$-cones}

It was previously reported that in fish the responses of an L-type horizontal cell to long-wavelength stimulation may be enhanced by a green background light. A hypothetical model of synaptic connections between cone photoreceptors and L-type cone horizontal cells has been proposed, which incorporates inhibitory feedback from horizontal cells to G-cones (Yang et al., 1982, 1983). If input from $\mathrm{R}$-cones is suppressed in prolonged darkness, the only input to L-type cone horizontal cells would be one from $\mathrm{G}$-cones and the interaction should not be observed. Figure 7 shows changes in the response to a $680 \mathrm{~nm}$ test flash $(\log I=-3.01)$ in the presence of a conditioning flash, which was a $500 \mathrm{~nm}$ flash $(\log I=-3.91)$ of relatively long duration $(1 \mathrm{sec})$, as a function of time in the dark. The retina was preadapted to a bright white light $(\log I=0)$ for $1 \mathrm{~min}$. The response to the test flash obtained at 5 min in darkness was enhanced by the presentation of the conditioning flash, compared with the control response (i.e., response to the test flash alone). As the retina was left in the dark longer, the control response decreased in size and the response was no longer enhanced by the conditioning flash. Indeed, the response to the test flash became smaller than the control. When the retina was dark-adapted for $120 \mathrm{~min}$, no response could be elicited by the test flash in the presence of the conditioning flash.

\section{Effects of intraocular injections of 6-OHDA}

We also examined the effects of intraocular injections of 6-OHDA on the dark suppression of L-type cone horizontal cells. Figure $8 a$ shows the average changes of response amplitudes of L-type cone horizontal cells to a $500 \mathrm{~nm}$ test flash $(\log I=-1.14)$ recorded from 6 -OHDA-treated fish $(n=5)$ as a function of time in the dark. In these experiments, the retinas were first dark-adapted for $2 \mathrm{hr}$ and then illuminated with bright $500 \mathrm{~nm}$ flashes $(500 \mathrm{msec}, \log I=-1.14)$ repetitively presented at $1 \mathrm{~Hz}$ until the response attained a maximum value. This amplitude was similar to the value obtained in untreated retinas under the same conditions. The retinas were then left in the dark and the responses decreased in size, but much less significantly than they did in untreated (control) retinas. Whereas the control re-

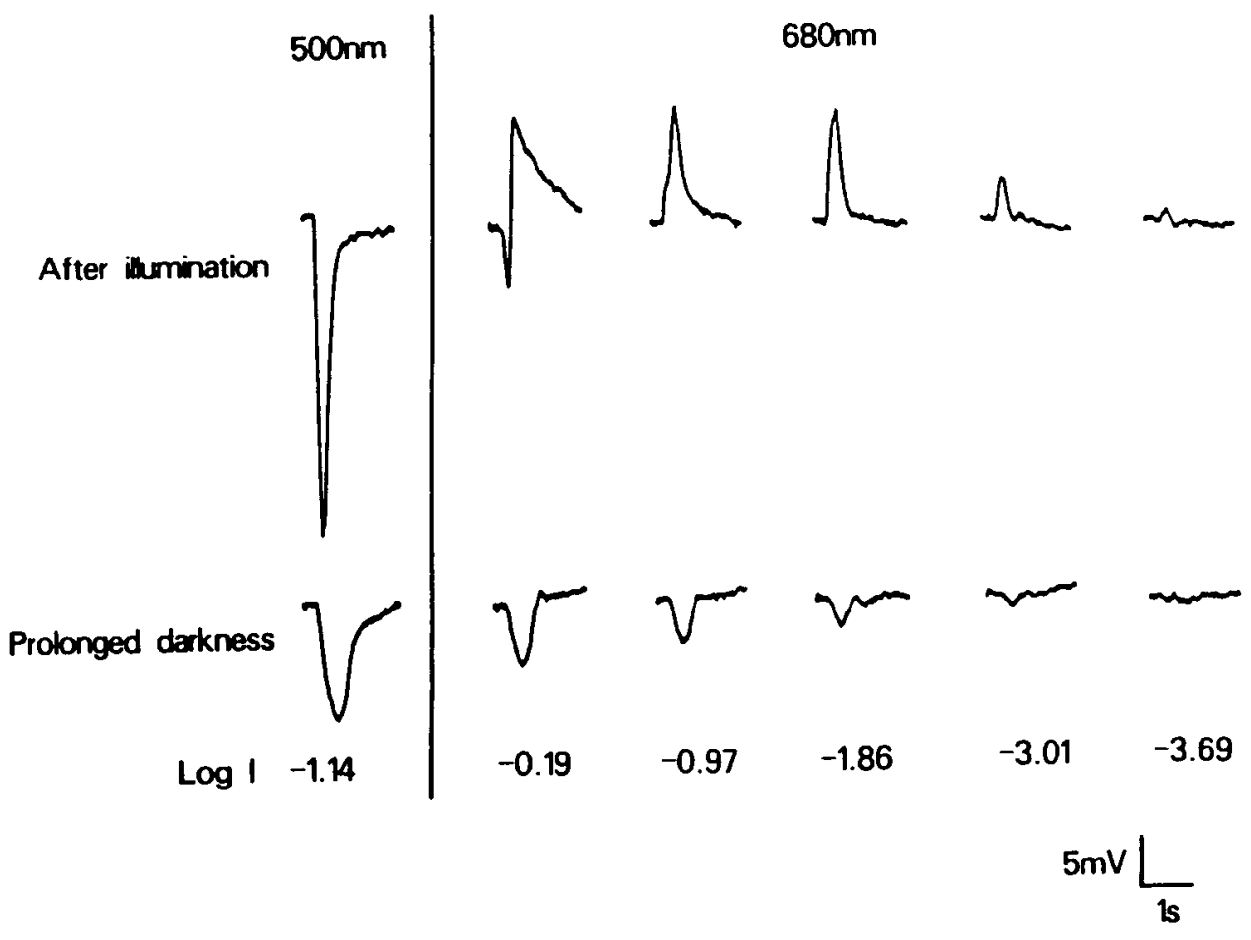

Figure 6. Changes in response waveforms of an R/G-type cone horizontal cell during prolonged dark adaptation. The retina was preexposed to a $1 \mathrm{~min}$ white light $(\log I=0)$. Responses to 500 $\mathrm{nm}$ and $680 \mathrm{~nm}$ flashes were recorded at 2 min (after illumination) and 150 min (prolonged darkness). The response to the $500 \mathrm{~nm}$ flash $(\log I=$ $-1.14)$ was a hyperpolarization, which decreased in size in prolonged darkness. The responses to $680 \mathrm{~nm}$ flashes of decreasing intensities $(-0.19,-0.97$, $-1.86,-3.01$, and -3.69 ) were mainly depolarizing just after background illumination was extinguished, but were all hyperpolarizing after prolonged darkness. 

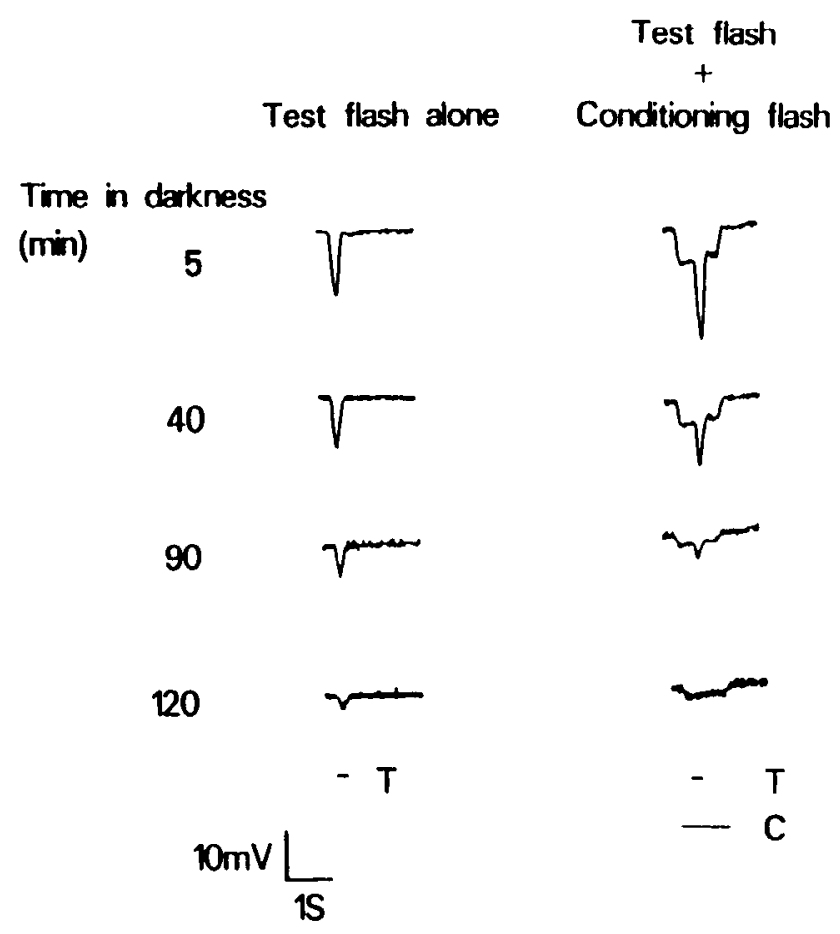

Figure 7. Effects of prolonged darkness on the interactions between inputs from red-sensitive and green-sensitive cones. Responses of an L-type cone horizontal cell to a test flash of $200 \mathrm{msec}(680 \mathrm{~nm}, \log I=$ -3.00 ) recorded at different times in darkness are shown in the left column, while those of the cell to the same flash in the presence of a conditioning flash $(500 \mathrm{~nm}, \log I=-3.91)$ of relative long duration (1 sec) are shown in the right column. Note that the response of the cell in the presence of the conditioning flash recorded at $5 \mathrm{~min}$ in the dark was bigger than that evoked by the test flash alone, but they were smaller when recorded at 40 and $90 \mathrm{~min}$. No response could be elicited by the test flash in the presence of the conditioning flash by $120 \mathrm{~min}$. Timing of test $(T)$ and conditioning $(C)$ flashes are indicated by horizontal bars on the bottom.

sponse recorded at 80 min was only $26.2 \pm 4.2 \%$ of the maximum one, the responses of the treated fish were $56.2 \pm 6.5 \%$ that of controls. This difference was statistically significant $(P$ $<0.005,($ tesl). Similar changes in the response amplitude were observed when red $(680 \mathrm{~nm}, \log I=-1.73)$ test flashes were used (Fig. $8 b$ ), but the decrease was even less significant: relative amplitude of the response recorded at $80 \mathrm{~min}$ from the treated fish was $63 \pm 7.4 \%$ of the maximum value, much larger than the control relative amplitude response, which was $21.2 \pm 3.4 \%$ $(P<0.005, t$ test $)$.

\section{Discussion}

In the present work we studied the effects of prolonged darkness on cone and rod horizontal cells in an in vivo carp preparation in which the retinal circulation was intact. It was found that the light responsiveness of L-type cone horizontal cells dramatically decreased with time in the dark. The longer the retina was left in the dark, the lower was the light responsiveness. In the in vivo fish preparation, response amplitudes of L-type cone horizontal cells to a bright test flash decreased from about $30 \mathrm{mV}$ to $3-5 \mathrm{mV}$ over a $150 \mathrm{~min}$ period, or about 10 -fold. This is strikingly different from earlier observations on isolated carp retinas: maximum response amplitudes of $\mathrm{L}$-type cone horizontal cells recorded from retinas isolated from prolonged $(>2$ hr) dark-adapted carp were typically about half the amplitude of cells from light-sensitized retinas (Mangel and Dowling, 1987;

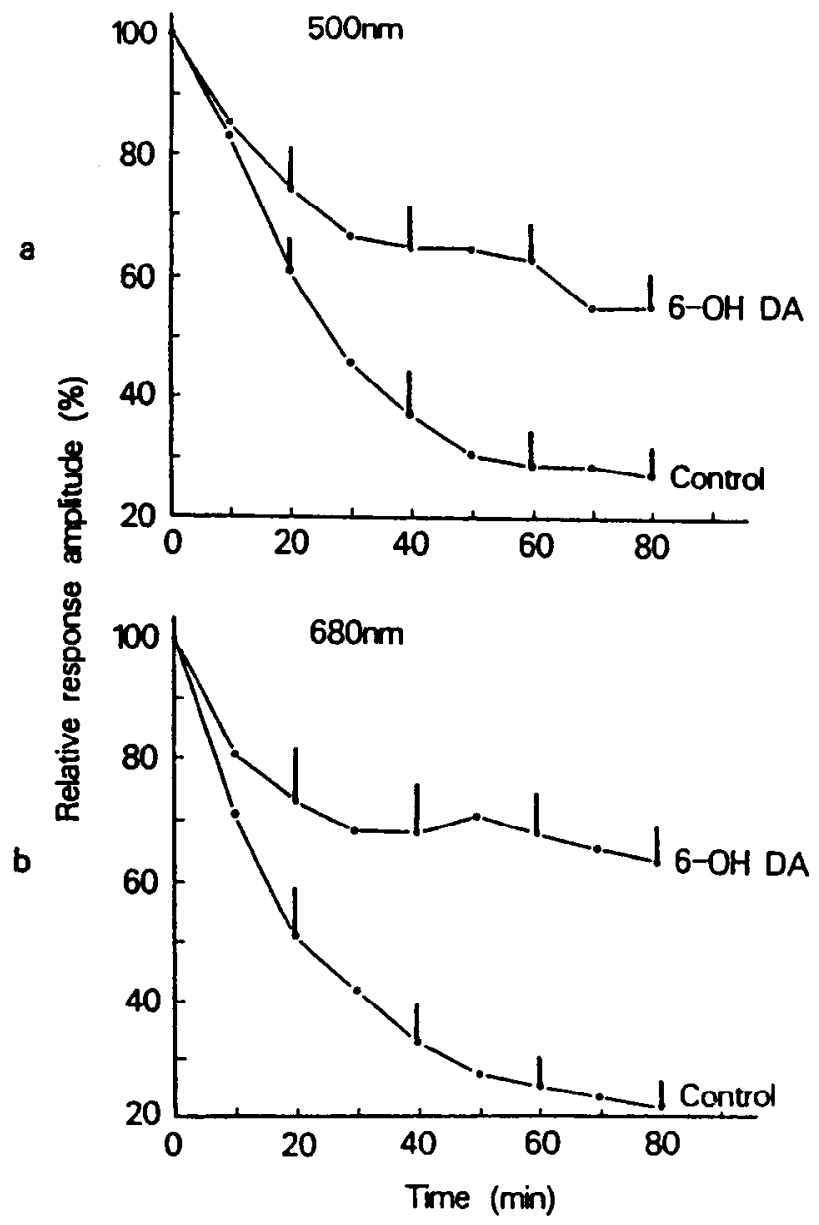

Figure 8. Effects of intraocular injections of 6-OHDA on dark adaptation of cone horizontal cells. The 6-OHDA retinas were first darkadapted for $2 \mathrm{hr}$ and then illuminated with bright green flashes (500 $\mathrm{nm}, \log I=-1.14)$ repetitively presented at $1 \mathrm{~Hz}$ to light-sensitize the response. Response amplitudes (open circles) to $500 \mathrm{~nm}(\log I=-2.14)$ and $680 \mathrm{~nm}(\log I=-1.73)$ test flashes determined at different times during dark adaptation were averaged $(n=5)$ and shown in $a$ and $b$. respectively. Both data were normalized in terms of values at $0 \mathrm{~min}$. Each data point represents the mean + SD. Relative amplitudes are plotted as a function of time in the dark and compared with those recorded from cells in untreated retinas $(n=5)$ under the same conditions (solid circles). Suppression observed in 6-OHDA-treated retinas was considerably less than that observed in untreated retinas.

Yang et al., 1988a). The difference found between isolated carp retinas and in vivo preparations could reflect the fact that a dim red light was used for dissecting and preparation setup, which might have sensitized L-type cone horizontal cells to some extent in the isolated retina. However, the same dim red light did not affect the isolated perch retina because maximum response amplitudes recorded from L-type cells from prolonged darkadapted perch were only about $4 \mathrm{mV}$ (Yang et al., 1988a).

Rod horizontal cells steadily increased in light responsiveness with time in the dark. As shown in Figure 2, rod horizontal cells did not show any response depression cven in prolonged darkness, indicating that the rod system is fully functional. This is also consistent with the result we reported previously (Yang et al., 1988a).

Our results further show that the extent of suppression by prolonged darkness differs between signals from different types of cones. In the L-type cone horizontal cells, responses to 680 
nm flashes, whether dim or bright, decreased in amplitude with increasing time in the dark, but this was not the case for responses to $500 \mathrm{~nm}$ flashes. Responses to a brighter $500 \mathrm{~nm}$ flash $(\log I=-1.14)$ invariably decreased in size, whereas those to $\operatorname{dim} 500 \mathrm{~nm}$ flashes increased during dark adaptation. L-type cone horizontal cells have been demonstrated to receive inputs from both R- and G-cones, but not from blue cones (Yang et al., 1982, 1983; Van Dijk, 1985). Since G-cones are around 3 $\log$ units less sensitive than R-cones at $680 \mathrm{~nm}$ (Hárosi and MacNichol, 1974; Yang et al., 1982), $680 \mathrm{~nm}$ flashes can be considered to activate $\mathrm{R}$-cones selectively. That responses to 680 flashes were reduced in size during dark adaptation suggests a suppression of input signal from $\mathrm{R}$-cones to L-type cone horizontal cells. On the other hand, as the sensitivity of R-cones is only $0.5 \mathrm{log}$ unit lower than that of G-cones at $500 \mathrm{~nm}$, a brighter $500 \mathrm{~nm}$ flash will stimulate not only $\mathrm{G}$-cones, but also R-cones to some extent. The dimmer a $500 \mathrm{~nm}$ flash, the less R-cones are stimulated. Thus, responses of L-type cone horizontal cells to the brighter $500 \mathrm{~nm}$ flashes probably reflect signals from both $\mathrm{R}$ - and G-cones, whereas responses to the dimmer $500 \mathrm{~nm}$ flashes are probably dominated by the contribution of $\mathrm{G}$-cones. A plausible explanation for the paradoxical changes in response amplitudes to brighter and dimmer $500 \mathrm{~nm}$ flashes may be as follows. The decrease in response to the brighter $500 \mathrm{~nm}$ flashes may simply reflect suppression of signal from R-cones and thus the response recorded at $65 \mathrm{~min}$ after the beginning of dark adaptation reflects mainly signals from $\mathrm{G}$-cones. That responses to dimmer $500 \mathrm{~nm}$ flashes increased with time in the dark may represent an increase of signal from G-cones. In other words, signals from $\mathrm{G}$-cones to L-type cone horizontal cells are not suppressed, if not enhanced, in prolonged darkness. Since signals from R-cones, but not from $\mathrm{G}$-cones, are depressed, these cells are primarily driven by input from $\mathrm{G}$-cones in prolonged darkness. This explanation is further supported by the fact that the spectral sensitivity of L-type cone horizontal cells determined at $65 \mathrm{~min}$ in the dark agreed well with that of G-cones (Fig. 5).

An alternative explanation is that the short-wavelength-sensitive photoreceptors providing input to L-type horizontal cells may be rods, but not G-cones (Mangel et al., 1993). Changes in light responsiveness of rod horizontal cells in the dark suggest that rod signals are not suppressed in prolonged darkness; thus, it might be possible that the increase in response amplitudes to dimmer $500 \mathrm{~nm}$ flashes reported here simply reflects an increase in rod signal during dark adaptation. Since the spectral sensitivity curve of rods peaks around $520 \mathrm{~nm}$ (Schwanzara, 1967) and coincides well with that of G-cones (compare Fig. 5 with Fig. 6 of Yang et al., 1990), it is difficult to judge whether the short-wavelength-sensitive photoreceptors sending input signal to L-type horizontal cells are G-cones or rods based on spectral characteristics of responses of the cells. We cannot rule out this possibility, but several lines of evidence seem to argue against this explanation. First, morphological investigations have not shown any connections between rods and L-type cone horizontal cells (Stell and Lightfoot, 1975; Stell et al., 1982). Although rods might communicate with cones through low-resistance gap junctions (Schwartz, 1975; Gold and Dowling, 1979), this coupling is thought to be weak in the dark (Attwell et al., 1984), but it can be strengthened by light (Yang and $\mathrm{Wu}, 1989$ ). Second, we previously reported that the spectral sensitivity curve of the L-type cone horizontal cells peaked around $520 \mathrm{~nm}$ when a bright red background light, strong enough to suppress rod activity, was presented to the retina (Tauchi et al., 1984; Yang,
1985). Ihis suggests that the short-wavelength-sensitive signal converging onto L-type cone horizontal cells is from G-cones rather than rods. Third, if the response recorded after prolonged darkness was driven by rod signals, it should have been suppressed by flashes of moderate intensity presented repetitively, but as shown in Figure $1 a$, the response increased in size with time during the presentation of the flashes.

Selective suppression of the R-cone signal during prolonged darkness was not limited to L-type cone horizontal cells; it was also observed in chromaticity, R/G-lype, biphasic horizontal cells. Although the depolarizing components to long-wavelength flashes were once thought to be driven by signals from presumptive deep red-sensitive cones (Naka and Rushton, 1966), we have previously demonstrated that it is signals from the common R-cones $\left(\lambda_{\max }=610 \mathrm{~nm}\right)$ that depolarize the $\mathrm{R} / \mathrm{G}$-type cone horizontal cells (Yang, 1987). Thus, the loss of the depolarizing component of these responses during prolonged darkness indicates a suppression of the R-cone signal.

Since exogenously applied dopamine mimics to a large extent the effects of prolonged darkness on cone horizontal cell responsiveness, it was earlier proposed that the dopaminergic interplexiform cells in fish may release dopamine tonically in the dark, thus suppressing the responsiveness of these cells (Mangel and Dowling, 1987; Yang et al., 1988b). On the other hand, some authors argue that dopamine is released primarily in the teleost retina during steady illumination (Dearry and Burnside, 1989; Kirsch and Wagner, 1989). It was found in the present study that the dark suppression of cone horizontal cells was much less significant when the dopaminergic interplexiform cells were destroyed. Moreover, although both responses of these cells to red and green flashes decreased in size with increasing time in the dark, the suppression was different in extent: responses to red flashes were less depressed than responses to green flashes. This is just opposite to the dark suppression observed in untreated retinas, in which responses to red flashes were more suppressed in prolonged darkness. These results are in accord with the supposition that dopamine is tonically released in prolonged darkness and suppresses the cone horizontal cells. Nevertheless, differences in light responsiveness of cone horizontal cells following 6-OHDA treatment were observed between the earlier work with isolated retinas and the in vivo preparations used here. Whereas in isolated retinas conc horizontal cells were no longer suppressed in prolonged darkness following the depletion of dopamine (Yang et al., 1988b), some suppression of responses was observed in the in vivo preparations. This suggests that a substance(s) other than dopamine may be involved in the dark suppression effect. An important difference between the in vitro and in vivo preparations is that modulation by centrifugal fibers is no longer available in isolated retinas. In teleost fish, centrifugal fibers that originate from the nucleus olfactoretinalis contact dopaminergic interplexiform cells (Zucker and Dowling, 1987). These fibers contain peptides-gonadotropin hormonereleasing hormone and FMRFamide (Munz et al., 1982; Stell et al., 1984)-and these peptides have been shown recently to regulate the activity of cone horizontal cells, presumably by modulating dopamine release from interplexiform cells (Umino and Dowling, 1991). It seems unlikely that these substances are involved in the suppression of cone horizontal cells observed in 6-OHDA-treated retinas, in which dopamine was depleted, unless they act directly on the cone horizontal cells. Another possibility is that the pigment epithelium somehow contributes to the dark suppression effect. 
Long-wavelength-induced depolarization in R/G-type horizontal cells is thought to be caused by a sign-inverting synaptic feedback from L-type horizontal cells onto G-cones (Stell, 1982), mediated by GABA (Tachibana and Kaneko, 1984). Indeed, blocking the GABA pathway abolishes the depolarizing response of R/G-type cells (Murakami et al., 1982), and some evidence has been presented that GABA is tonically released in the dark-adapted goldfish retina (Marc et al., 1978; Ayoub and Lam, 1984; Yazulla, 1985). GABA application also causes anatomical changes in the outer plexiform layer similar to that which occurs in the dark and which may result in a less effective feedback from L-type cone horizontal cells to G-cones (Wagner, 1980; Weiler and Wagner, 1984). Thus, dark release of GABA from L-type cells may be one possible mechanism underlying the loss of the depolarizing component of $\mathrm{R} / \mathrm{G}$-type cell responses to long-wavelength flashes in prolonged darkness. However, the mechanism underlying the more significant suppression of R-cone signal to L-type cells in prolonged darkness remains to be elucidated.

\section{References}

Attwell D, Wilson M, Wu SM (1984) A quantitative analysis of interactions between photoreceptors in the salamander (Ambystoma) retina. J Physiol (Lond) 352:703-737.

Ayoub GS, Lam DMK (1984) The release of $\gamma$-aminobutyric acid from horizontal cells of the goldfish (Carassius auratus) retina.J Physiol (Lond) 355:191-214.

Dearry A, Burnside B (1989) Light-induced dopamine release from teleost retinas acts as a light-adaptive signal to the retinal pigment epithelium. J Neurochem 53:870-879.

Gold CH, Dowling JE (1979) Photoreceptor coupling in retina of the toad, Bufo marinus. I. Anatomy. J Neurophysiol 42:292-310.

Hárosi FI, MacNichol EF Jr (1974) Visual pigments of goldfish cones. Spectral properties and dichroism. J Gen Physiol 63:179-204.

Kaneko A (1970) Physiological and morphological identification of horizontal, bipolar and amacrine cells in the goldfish retina. J Physiol (Lond) 207:623-633.

Kaneko A, Yamada H (1972) S-potentials in the dark-adapted retina of the carp. J Physiol (Lond) 227:261-273.

Kirsch M, Wagner H (1989) Release pattern of endogenous dopamine in teleost retina during light adaptation and pharmacological stimulation. Vision Res 29:147-154.

Mangel SC, Dowling JE (1987) The interplexiform-horizontal system of the fish retina: effects of dopamine, light stimulation and time in the dark. Proc R Soc Lond [Biol] 231:91-121.

Mangel SC, Baldridge WH, Weiler R, Dowling JE (1993) Cone input to fish cone horizontal cells is reduced and rod input is present following prolonged darkness. Invest Ophthalmol Vis Sci (ARVO abstract) 34:1292.

Marc RE, Stell WK, Box D, Lam DMK (1978) GABA-ergic pathways in the goldfish retina. J Comp Neurol 182:221-246.

Munz H, Class B, Stump WE, Jennes L (1982) Centrifugal innervation of the retina by luteinizing hormone releasing hormone (LHRH-immunoreactive telencephalic neurons in teleostean fishes). Cell Tissue Res 222:313-323.

Murakami M, Shimoda Y, Nakatani K, Miyachi E, Watanabe S (1982) GABA-mediated negative feedback and color opponency in carp retina. Jpn J Physiol 32:927-935.

Naka KI, Rushton WAH (1966) S-potentials from colour units in the retina of fish (Cyprinidae). J Physiol (Lond) 185:536-555.
Parthe V (1982) Horizontal cells in the teleost retina. In: The S-potential (Drujan BD, Laufer M, eds), pp 31-49. New York: Liss.

Schwanzara SA (1967) The visual pigments of fresh water fishes. Vision Res 7:121-148.

Schwartz EA (1975) Cones excite rods in the retina of the turtle. J Physiol (I ond) 246:639-651

Spekreijse H, Mooy JEM, van den Berg TJTP (1981) Photopigments and carp ganglion cell action spectra. Vision Res 21:1601-1604.

Stell WK, Lightfoot DO (1975) Color-specific interconnections of cones and horizontal cells in the retina of the goldfish. J Comp Neurol 159: 473-502.

Stell WK, Kretz R, Lightfoot DO (1982) Horizontal cell connectivity of goldfish. In: The S-potential (Drujan BD, Laufer M, eds), pp 5175. New York: Liss.

Stell WK, Walker SE, Chohan KS, Ball AK (1984) The goldfish nervous terminalis: a luteinizing hormone-releasing hormone and molluscan cardioexcitatory peptide immunoreactive olfactoretinal pathway. Proc Natl Acad Sci USA 81:940-944.

Tachibana M. Kaneko A (1984) $\gamma$-Aminobutyric acid acts at axon terminals of turtle photoreceptor: difference in sensitivity among cell types. Proc Natl Acad Sci USA 81:7961-7964.

Tauchi M, Yang XL, Kaneko A (1984) Depolarizing responses of L-type external horizontal cells in the goldfish retina under intense chromatic background. Vision Res 24:867-870.

Umino O, Dowling JE (1991) Dopamine release from interplexiform cells in the retina: effects of GnRH, FMRFamide, bicuculline, and enkephalin on horizontal cell activity. J Neurosci 11:3034-3046.

Van Dijk BW (1985) The functional organization of carp and goldfish retina. An electrophysiological study of color interactions in vertebrate retina. $\mathrm{PhD}$ thesis, University of Amsterdam.

Wagner HJ (1980) Light dependent plasticity of morphology of horizontal cell terminals in cone pedicles of fish retinas. J Neurocytol 9:573-590.

Weiler R, Wagner HJ (1984) I ight-dependent change of cone-horizontal cell interactions in carp retina. Brain Res 298:1-9.

Werblin FS, Dowling JE (1969) Organization of the retina of the mudpuppy, Necturus maculosis. II. Intracellular recording. J Neu rophysiol 32:339-355.

Yang XL (1985) Cone input signals to L-type external horizontal cells of the cyprinid retina. Acla Physiol Sin 37:307-315.

Yang XL (1987) Photoreceptor inputs converging onto C-type horizontal cells of crucian carp retina. Sci Sin [Ser B] 30:33-43.

Yang XL, Wu SM (1989) Modulation of rod-cone coupling by light. Science 244:352-354.

Yang XL, Tauchi M, Kaneko A (1982) Quantitative analysis of photoreceptor inputs to external horizontal cells in the goldfish retina Jpn J Physiol 32:399-420.

Yang XI, Tauchi M, Kaneko A (198.3) Convergence of signals from red-sensitive and green-sensitive cones onto L-type external horizontal cells of the goldfish retina. Vision Res 23:371-380.

Yang XL, Tornqvist K, Dowling JE (1988a) Modulation of cone horizontal cell activity in the teleost fish retina. 1 . Effects of prolonged darkness and background illumination on light responsiveness. J Neurosci 8:2259-2268.

Yang XL, Tornqvist K, Dowling JE (1988b) Modulation of cone horizontal cell activity in the teleost fish retina. II. Role of interplexiform cells and dopamine in regulating light responsiveness. J Neurosei 8:2269-2278

Yang XL, Fan TX, Li JD (1990) Electroretinographic b-wave merely reflects the activity of the rod system in the dark-adapted carp retina. Vision Res 30:993-999.

Yazulla S (1985) Evoked efflux of [ $\left.{ }^{3} \mathrm{H}\right]$ GABA from goldfish retina in the dark. Brain Res 325:171-180.

Zucker CL. Dowling JE (1987) Centrifugal fibers synapse on dopaminergic interplexiform cells in the teleost retina. Nature 330:166168. 